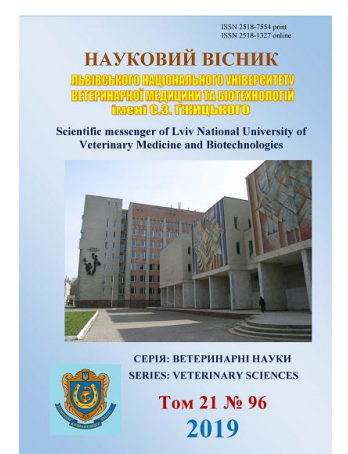

\author{
Науковий вісник Львівського національного університету \\ ветеринарної медицини та біотехнологій імені С.3. Гжицького. \\ Серія: Ветеринарні науки
}

\title{
The role of osteodystrophy in the pathogenesis of aseptic pododermatitis in cows
}

\author{
N.M. Khomyn ${ }^{1}$, A.R. Mysak ${ }^{1}$, S.V. Tsisinska ${ }^{1}$, V.V. Pritsak ${ }^{1}$, Yu.M. Lenyo ${ }^{1}$, M.M. Khomyn ${ }^{2}$ \\ ${ }^{1}$ Stepan Gzhytskyi National University of Veterinary Medicine and Biotechnologies Lviv, Ukraine \\ ${ }^{2}$ Institute of Animal Biology NAAS, Lviv, Ukraine
}

Article info

Received 15.10.2019

Received in revised form 16.11.2019

Accepted 17.11.2019

Stepan Gzhytskyi National University of Veterinary Medicine and Biotechnologies Lviv, Pekarska Str., 50, Lviv, 79010, Ukraine. Tel.: +38-067-894-17-12 E-mail:nadiakhomyn@ukr.net

Institute of Animal Biology of NAAS, Stusa Str., 38, Lviv, 79000, Ukraine.
Khomyn, N.M., Mysak, A.R., Tsisinska, S.V., Pritsak, V.V., Lenyo, Yu.M., \& Khomyn, M.M. (2019). The role of osteodystrophy in the pathogenesis of aseptic pododermatitis in cows. Scientific Messenger of Lviv National University of Veterinary Medicine and Biotechnologies. Series: Veterinary sciences, 21(96), 129-133. doi: 10.32718/nvlvet9623

It is well known that the value of full feeding of farm animals is an important condition for the production of livestock products. Because of the researches of many scientists was found that the value of feed is determined by the content of proteins, fats, carbohydrates, as well as vitamins, minerals and so on. However, the true value of the feed is determined by the part that is digestible and can be used by the body in the metabolism process. In the event of a violation of feeding level associated with the lack of nutrients or minerals of animals or their deficiency, the development of osteodystrophic processes is observed, which directly contribute to changes in the tendon-ligamentous apparatus of the finger of animals, there is an occurrence of prolonged osteotendinitis of the finger flexors, which causes to fingers extension, partially or completely removed from the hoof wall support, and overload of crumbs. Tightening of the crumb support is accompanied by the appearance of the skin of the hoof inflammatory process, excessive horn growth and deformation of the horn capsule. The final confirmation of osteodystrophy is the results of a multivariate mass volumetric analysis of the skeleton state and determination of the magnitude of the angles of the joints of the fingers. On the side of the hoof horn, there is an increase in the moisture content and SH-groups and a decrease in $\gamma$-keratosis, which affects the biophysical properties of the hoof horn, which are shown by a decrease in density and hardness. Such changes indicate a deterioration in the quality of the hoof horn, a confirmation of which is a decrease in the intensity of erasing of the sole horn, the development of deformation and the occurrence of aseptic inflammation of the base of the skin of the sole horn.

Key words: cattle, hoof epidermis, deformation, feeding, biophysical and biochemical parameters.

\section{Роль остеодистрофії у патогенезі асептичного пододерматиту у корів}

\author{
Н.М. Хомин ${ }^{1}$, А.Р. Мисак ${ }^{1}$, С.В. Цісінська ${ }^{1}$, В.В. Прицак ${ }^{1}$ Ю.М. Леньо ${ }^{1}$, М.М. Хомин ${ }^{2}$ \\ ${ }^{1}$ Львівський національний університет ветеринарної медицини та біотехнологій імені С.З. Гюицького, м. Львів, \\ Украӥна \\ ${ }_{2}^{2}$ Інститут біології тварин НААН, м. Львів, Украӥна
}

Відомо, щуо значення повноиінної годівлі сільськогосподарських тварин є важливою умовою виробництва тваринницькой продукиіі. Дослідженнями багатьох вчених встановлено, щьо цінність кормів визначається вмістом у їх складі білків, жсрів, вуглеводів, а також вітамінів, мінеральних речовин тощз. Однак, справжня цінність корму визначається тією його частиною, яка здатна перетравлюватися і може бути використана організмом у прочесі обміну речовин. За умов порушення рівня годівлі, пов'язаного з неодоодержанням організмом тварин поживних та мінеральних речовин або їх дефіичиту, особливо кальиію, фосфору, а також вітаміну Di A спостерігається розвиток остеодистрофічних прочесів, які, безпосередньо сприяють змінам сухожилковозв'язкового апарата пальия тварин, ше проявлясться виникненням пролонгуючого остеотендиніту пальцевих згиначів, ияо призводить до перерозгинання пальців, часткового або повного виключення з опори копитцевих стінок та перевантаження м'якушів. Посилення опори на м'якуші супроводжується виникненням в основі шкіри копитець запального процесу, надмірним відростанням рогу та деформацією рогової капсули. Остаточним підтвердженням наявності остеодистрофії є результати багатофакторного 
мас-об'ємного аналізу стану кістяка та визначення величини кутів суглобів пальців. Збоку копитцевого рогу має місие підвищення вмісту вологи і SН-груп та зниження конщентрації кальцію, сульфуру, ү-кератоз, щчо впливає на біофізичні властивості рогу копитець, які проявляються зменшенням шільності та збільшенням опору до стирання. Такі зміни свідчать про погіршення якості копитцевого рогу, підтвердженням чому є зниження інтенсивності стирання рогу підошви, шо призводить до розвитку деформації та виникнення асептичного запалення основи шкіри підошви копитець.

Ключові слова: худоба, епідерміс копитець, деформація, годівля, біофізичні і біохімічні показники.

\section{Вступ}

У сучасних умовах ведення скотарства, особливо у зимово-стійловий період утримання тварин їх копитця нерідко зазнають впливу різних несприятливих факторів, перш за все пов'язаних з похибками у годівлі, оскільки відомо, що життєдіяльність тварин нерозривно пов'язані з надходженням в організм поживних речовин корму та макро- і мікроелементів, які $є$ джерелом обмінних процесів (Borysevych et al., 1993; Borisevich, 1996). Встановлено також, що інтенсивність обміну речовин у значній мірі обумовлюється повноцінним раціоном, тобто залежать від рівня живлення (Kantemir,1997; Khomyn et al., 2017)

Рівень годівлі поряд 3 умовами утримання має безпосередній вплив на продуктивність та загальний стан тварин. Зокрема, незадовільні умови годівлі, тобто незбалансованість раціонів корму за поживними речовинами та макро- і мікроелементами, а також дефіцит їх в раціонах зумовлюють порушення обміну речовин, що сприяє розвитку остеодистрофії (Borysevych, 1983).

Мета роботи. Вивчення впливу остеодистрофії на стан сухожилково-зв'язкового апарату і кісткової тканини копитець, копитцевого рогу та виникнення асептичного пододерматиту у корів.

\section{Матеріал і методи досліджень}

Дослідження проводили у господарствах Львівської області на коровах чорно-рябої породи у зимовостійловий період за прив'язного утримання тварин. Сформували 2 групи корів (контрольна і дослідна) по 5 тварин у кожній, підібраних за принципом аналогів щодо віку, маси тіла, продуктивності. У тварин контрольної групи, (клінічно здорові) яким згодовуввали корми господарського раціону збережена вісь пальцевих кісток, а у корів дослідної ( хворі на аліментарну дистрофію, підтверджену результатами клінічних та біохімічних досліджень), яким згодовували корми раціону, незбалансованого та дефіцитного за поживними та міеральними речовинами спостерігалось порушення осі пальцевих кісток. Проведені клінічні дослідження, які включали визначення загального стану тварин та встановлення типу кульгавості. Стан кінцівок оцінювали шляхом огляду, пальпації та вимірювання кутів суглобів суглобовим кутоміром. Стан кістяка тварин оцінювали оглядом, пальпацією, а також проводили трепанобіопсію кісткової тканини у ділянці зовнішнього горба клубової кістки з наступним проведенням багатофакторного мас-об'ємного аналізу отриманих трепанобіоптатів (типова губчаста кістка, у вічках якої знаходиться жировий (жовтий) кістковий мозок) за В.Б. Борисевичем (Borysevych, 2000), який полягав у визначенні щільності нативної сирої кістки, сухої знежиреної кістки, органічного матриксу, мінеральних речовин та індексу мінералізації. Визначення вмісту у копитцевому розі вологи, кальцію, фосфору, сульфуру, концентрації SH-груп та кератоз, а також щільності епідермісу копитцець, його опору до стирання та інтенсивність росту і стирання проводили згідно загально прийнятих методик.

Отримані числові дані обробляли за допомогою стандартного пакету статистичних програм Microsoft EXCEL.

\section{Результати та їх обговорення}

Під час проведення диспансеризації з метою виявлення ортопедичної патології у худоби перш за все звертають увагу на виражені ознаки копитної деформації, а менш помітний остеодистрофічний симптомокомплекс часто не враховують, через що складається недостатньо повне уявлення про характер порушення функції локомоторного апарата корів (Borysevych et al.,1997). Відомо, що за умов зимовостійлового утримання тварин та згодовування їм кормів раціонів, дефіцитних та незбалансованих за поживними та мінеральними речовинами розвиваються аліментарна остеодистрофія, яка згодом ускладнюється деформацією та супутніми хворобами копитець.

Так, асептичне запалення основи шкіри копитець у корів більш ніж вдвічі частіше реєструють у господарствах з низьким рівнем годівлі, що складає 68,4\% проти $31,6 \%$ у господарствах, де тварини отримують корми раціону, збалансовані за поживними та мінеральними речовинами (господарський раціон).

При цьому, виявляли як деформації копитець, так і аліментарну остеодистрофію. Розрив у часі між двома цими патологічними проявами становить у середньому 5-14 місяців і значною мірою залежить від інтенсивності остеодистрофічного процесу.

На першій, початковій стадії патологічного процесу, а саме: остеодистрофія - (порушення постави кінцівок) - деформація копитець клінічно, як відомо, визначаються, загалом симптоми остеодистрофічних уражень: розвивається розм'якшення і навіть розсмоктування останніх хвостових хребців, розхитуванням зубів тощо.

На другій, клінічно вираженій стадії ураження кінцівок спостерігаються зміни суглобових кутів пальців, дорзальні заломи пальцевих осей та зміни кутів зачепів (Borysevych, 1993), тоді як за нормальної постави кінцівок кут зачепа копитець грудної кінцівки становить 53,2 $\pm 1,41^{\circ}$, копитець тазових кінцівок 47,2 $\pm 0,76^{\circ}$ (Borisevich, 1996). Саме за такої величи- 
ни кута відбувається оптимальний фізіологічний розподіл опорно-силових навантажень у структурах копитець: стінки відіграють основну опорну роль, а м'якуш - здебільшого амортизаційну.

Дослідженнями встановлено, що у тварин дослідної групи мало місце вірогідне перерозгинання путового, вінцевого та копитного суглобів на 48,3\%, 45 та $28 \%$, що складає відповідно $114,5 \pm 4,19^{\circ}-115,4 \pm$ $3,49^{\circ}$ та $119,4 \pm 4,34^{\circ}$. Воно зумовлене подовженням сухожилків і зв'язок у ділянках прикріплення до кісток, що контролюють у стані натягу суглобові кути, які зазнають гіперекстензї̈ (пальцеві суглоби). Такий патологічний стан визначається як дистрофічний остеотендиніт (-десмоїдит), який у всіх без виключення випадках супроводжується ураженням копитець, в основному, запального характеру (протікає субклінічно); здебільшого реєструють асептичний пододерматит.

Остаточним свідченням наявності остеодистрофічних порушень у корів з патологією пальців та симптомами асептичного пододерматиту були дані, отримані за умов безпосереднього вивчення стану кістяка, зокрема проведення багатофакторного мас-об'ємного аналізу (табл. 1).

\section{Таблиця 1}

Показники трепанобіоптатів кістяка корів у нормі та 3 перерозгинанням пальців і пододерматитом $(\mathrm{M} \pm \mathrm{m}, \mathrm{n}=5)$

\begin{tabular}{|c|c|c|}
\hline Показники & $\begin{array}{c}\text { Корови із збереженням осі } \\
\text { пальцевих кісток } \\
\text { (контрольна група) }\end{array}$ & $\begin{array}{c}\text { Корови із порушенням осі пальцевих } \\
\text { кісток та пододерматитом } \\
\text { (дослідна група) }\end{array}$ \\
\hline 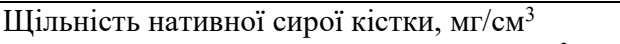 & $1108,5 \pm 100,45$ & $785,0 \pm 70,67 *$ \\
\hline 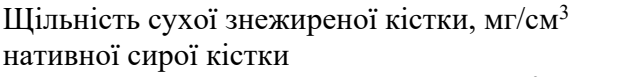 & $378,4 \pm 35,12$ & $240,6 \pm 23,18^{*}$ \\
\hline 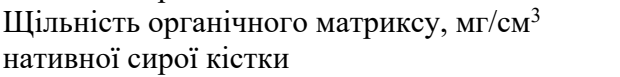 & $125,7 \pm 11,89$ & $102,0 \pm 9,23$ \\
\hline 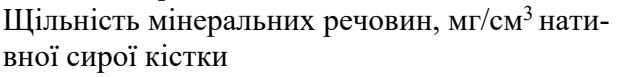 & $252,7 \pm 24,57$ & $166,7 \pm 15,75^{*}$ \\
\hline Індекс мінералізації & $2,01 \pm 0,128$ & $1,43 \pm 0,005 * *$ \\
\hline
\end{tabular}

Примітка: *-P <0,05, **-P <0,01 - вірогідна різниця порівняно $з$ показниками контрольної групи

Результати досліджень показали, що у корів з патологією пальців та симптомами пододерматиту статистично вірогідна різниця встановлена майже щодо усіх компонентів, які відображають стан кістяка. Так, щільність нативної сирої кістки у корів 3 порушенням осі пальцевих кісток та пододерматитом була на 41,2\% нижчою порівняно 3 аналогічним показником контрольної групи, щільність знежиреної кістки - на $57,3 \%$, щільність мінеральних речовин - на 51,6\%. Величина індекса мінералізації була нижчою на 40,6\%, що становить $1,40 \pm 0,090$ проти 2,01 $\pm 0,039$ кісткової тканини корів контрольної групи.

Як видно з таблиці чотири показники 3 п'яти за умов проведення багатофакторного мас-об'ємного аналізу трепанобіоптатів статистично вірогідно різняться між собою, причому у корів 3 деформацією копитець значно менша щільність як сирої, так і сухої знежиреної кістки, а також менший вміст мінеральних компонентів. Досить низьке співвідношення кількості мінералів і матриксу в корів з ураженням локомоторного апарата свідчить про наявність процесу остеодистрофії, який у цьому випадку є провідною ланкою у виникненні патології копитець.

Отже, в основі дистрофічного остеотендиніту (-десмоїдиту) лежить зменшення міцності фіксації сухожилків і зв'язок до кістки, очевидно, зумовлене зниженням мінеральної насиченості і виникненням тут мляво протікаючого хронічного запалення.

Проведене дослідження дає підстави чітко представити етіопатогенез уражень копитець, спричинених незадовільним рівнем годівлі (схема 1).

\section{Схема 1}

Етіопатогенез уражень копитець, зумовлений похибками у годівлі

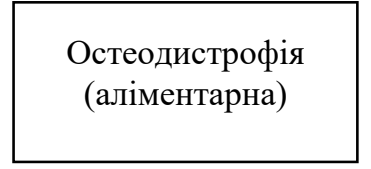

Отже, важливим чинником, який сприяє виникненню асептичного пододерматиту у корів є остеодистрофія. На тлі остеодистрофічних уражень виникає дистрофічний остеотендиніт пальцевих згиначів, що призводить до перерозгинання пальців, часткового або повного виключення з опори копитцевих стінок та
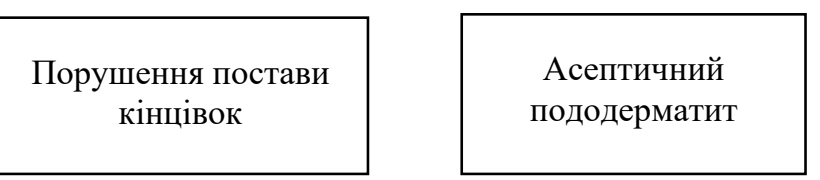

перевантаження м'якушів. Посилення опори на м'якуші супроводжується надмірним відростанням рогу і деформацією рогової капсули.

Так, в умовах дефіциту мінеральних та поживних речовин в організмі тварин дослідної групи спостерігається вірогідне збільшення вмісту у копитцевому 
розі вологи на 7,3\%, шо складає $39,3 \pm 2,02 \%$ проти $32,2 \pm 1,85$ та SН-груп - на $34 \%$ або 45,2 $\pm 1,79$ мкмоль/г проти $33,7 \pm 0,47$ в контрольній групі. Вище означені зміни свідчать про погіршення якості епідермісу копитець, що підтверджується характером співвідношень окремих фракцій кератоз, яке полягає у зменшенні концентрації $\gamma$-кератоз на 2,4\% (табл. 2).

\section{Таблиця 2}

Біохімічні показники копитцевого рогу $(\mathrm{M} \pm \mathrm{m}, \mathrm{n}=5)$

\begin{tabular}{lcc}
\hline \multicolumn{1}{c}{ Показники } & \multicolumn{2}{c}{ Групи } \\
\cline { 2 - 3 } контрольна & дослідна \\
\hline Волога, \% & $32,2 \pm 1,85$ & $39,3 \pm 2,02^{*}$ \\
Кератози, \%: & $63,3 \pm 1,20$ & $65,6 \pm 1,75$ \\
$\quad$ - альфа, & $15,5 \pm 0,27$ & $15,7 \pm 0,51$ \\
$\quad$ - бета, & $1,82 \pm 0,27$ & $18,7 \pm 0,16^{* * *}$ \\
$\quad$ - гама & $1,23 \pm 0,017$ & $1,60 \pm 0,027^{* *}$ \\
Кальцій, г/кг 13,6 & $17,84 \pm 0,357$ & $15,26 \pm 0,057$ \\
Фосфор, г/кг & $33,7 \pm 0,47$ & $45,2 \pm 1,79^{* * *}$ \\
Сульфур, г/кг 17,0 & & \\
SН-групи, мкмоль/г & & \\
\hline
\end{tabular}

Примітка: *- $\mathrm{P}<0,05, * *-\mathrm{P}<0,01, * * *-\mathrm{P}<0,001-$ вірогідна різниця порівняно з показниками контрольної групи

Відомо, що $\gamma$-кератози, які входять до складу цементуючої речовини є сульфатованими мукополісахаридами, які беруть безпосередню участь у кератоутворенні, а зменшення їх концентрації свідчить про порушення процесу кератинізації і погіршення якості копитцевого рогу, підтвердженням чого є зменшення у копитцевому розі вмісту сульфуру на $17 \%$. Поряд 3 цим спостерігається зменшення у цій частині копитець концентрації так званого лабільного кальцію на $13,6 \%$, вміст якого регулюється надходженням 3 кормів раціону, що безпосередньо негативно впливає на стан епідермісу копитець.

Встановлено, що зміни біохімічних показників копитцевого рогу вплинули на його біофізичні параметри. Так, вірогідно нижчий на 4,2\% показник щільності, який складає $1,131 \pm 0,0034$ проти

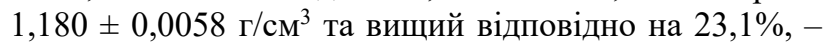
опору до стирання, що становить $116,2 \pm 5,09$ проти $94,4 \pm 5,16$ об/мм.

На нашу думку, такі зміни, очевидно, вплинули на інтенсивність росту і стирання рогу підошви копитець. Зокрема, у тварин дослідної групи інтенсивність росту копитцевого рогу знизилася на $16,2 \%$, що складає 6,2 $\pm 0,39$ мм/міс, а стирання - на 50,7\% і становить $3,3 \pm 0,37$ мм/міс. При цьому у корів дослідної групи спостерігається наростання рогу підошви та деформація копитець.

Отже, недоодержання організмом корів поживних i мінеральних речовин, а також незбалансованість кормів раціонів у зимово-стійловий період утримання сприяють виникненню аліментарної остеодистрофії, яка $\epsilon$ пусковим механізмом розвитку деформації копитець на грунті погіршення якості епідермісу копитець, порушення постави кінцівок, підтвержене ре- зультатами біохімічних і біофізичних досліджень та виникнення у цій ділянці пальця асептичного пододерматиту.

\section{Висновки}

1. Похибки у годівлі та виникнення на їх тлі аліментарної остеодистрофії, підтвердженням якої $\epsilon$ результати багатофакторного мас-об'ємного аналізу стану кістяка та визначення величини кутів суглобів пальців сприяють розвитку дистрофічного остеотендиніту (-десмоїдиту) розгиначів пальців i, як наслідок, порушенню рівномірного розподілу навантаження на підошву, виникненню деформації та порушення постави кінцівок.

2. За остеодистрофії у копитцевому розі корів спостерігаєтся підвищення вмісту вологи і SH-груп на 7,3 і 34\% та зниження концентрації кальцію, сульфуру на 13,6 та $17,0 \%$, а також $\gamma$-кератоз на 2,4\%, що впливає на біофізичні властивості епідермісу копитець, які проявляються зменшенням щільності на 4,2\% та підвищенням опору до стирання відповідно на 23,1\%, тобто погіршенням якості копитцевого рогу, надмірним наростанням рогу підошви, деформацією копитець, порушенням постави та розвитком асептичного пододерматиту.

Перспективи подальших досліджень. Дослідження будуть спрямовані на пошук нових методів покращення якості копитцевого рогу корів 3 метою попередження виникнення $\mathrm{i}$ розвитку асептичного пододерматиту.

\section{References}

Borysevych, V.B. (2000). Bagatofaktornyi mas-obemnyi analiz kistkovoyi tkanyny. Visnyk agrar. nauky, 3, 35-38 (in Ukrainian).

Borisevich, V.B. (1996). Veterinarnaja ortopedija (bolezni kopytec i kopyt): posinik. Kirovograd: Kirovogradgosizdat (in Russian).

Borysevych, V.B. (1983). Deformatsiya kopyitets krupnogo rogatogo skota (Anatomicheskoe, gistologicheskoe, gistohimicheskoe, klinicheskoe i patologoanatomicheskoe issledovanie). Avtoref. diss... d-ra. vet. nauk: 16.00.05. Moskva (in Russian).

Borysevych, V.B., Luschik, A.A., \& Bashmak, N.I. (1997). K patogenezu deformirovannyih kopyitets krupnogo rogatogo skota s krohkim i lomkim rogom. Diagnostika, terapiya i profilaktika bolezney selskohozyaystvennyih zhivotnyih: Nauch. trudyi Ukr. s.-h. akademii, 190, 31-34 (in Russian).

Borysevych, V.B., Tkachenko, S.M., Borysevych, B.V. ta in. (1993). Distrofichnyi osteotendynit koriv. Visnyk agrar. nauky, 11, 69-73 (in Ukrainian).

Kantemir, O.V. (1997). Rozpovsyudzhennya i prychyny vynyknennya zahvoryuvan distalnogo viddilu kintsivok velykoyi rogatoyi hudoby $\mathrm{v}$ umovah kompleksu. Veterinarna meditsina: Mizhvidom. temat. nauk. zb., 73, 86-88 (in Ukrainian). 
Khomyn, N.M., Mysak, A.R., Iglitskej, I.I., \& Pritsak, V.V. (2017). Prevalance and causes of diseases occurrence of cows hooves. Scientific Messenger LNUVMBT named after S.Z. Gzhytskyj, 19(77), 2226. doi: $10.15421 /$ nvlvet7706.

Khomyn, N.M., Mysak, A.R., Tsisinska, S.V., \& Pritsak, V.V. (2017). The quality of the hoof horns of cattle and the influence of certain etiological factors.
Scientific Messenger LNUVMB, 19(82), 175-179. https://nvlvet.com.ua/index.php/journal/article/view/1 360.

Khomyn, N.M., Mysak, A.R., Iglitskej, I.I., Pritsak, V.V., \& Semeniyk, N.V. (2017). Treatment of dogs for periodontal diseases. Scientific Messenger LNUVMB, 19(82), 170-174. https://nvlvet.com.ua/ index.php/journal/article/view/1359. 